\title{
Comparative analysis of calculations of strip foundation, taking into account the influence of adjoined building with different soil models
}

\author{
Nataliia Lobacheva ${ }^{1, *}$ and Vadim Griniov ${ }^{2}$ \\ ${ }^{1}$ Moscow State University of Civil Engineering, Yaroslavskoe shosse, 26, Moscow, 129337, Russia \\ ${ }^{2}$ Belarusian National Technical University, Nezavisimosty Ave., 65, Minsk, 220013, Belarus
}

\begin{abstract}
The necessity to take into account the properties of soil foundations, which depend not only on the conditions of their natural occurrence, but also on the stress state, led researchers to create a large number of different soil models. This article provides is to clarify the patterns and features of the three-dimensional interaction of strip foundations with the soil base in conditions of dense urban development with the use of various design soil models and comparison with field observations. Three soil models (the Mohr-Coulomb model, the Hardening-Soil model, model of the Klepikov stiffness coefficient) are considered. The calculation stages displayed a true picture of the construction of a new building (dismantling of the floor of an existing building, excavation, etc.). As a result of numerical experiments with a use of Plaxis and methods for calculating structures on a deformable base was received values settlement of strip foundations in applying three soil models. The difference of the calculated values of strip foundation settlement is defined in percentage. The geodesic monitoring confirms the validity of the research.
\end{abstract}

\section{Introduction}

Nowadays, there have been major modifications in the practice of construction and building operation. Requirements for buildings, requirements for reliability and durability were increased. Buildings are raised increasingly frequently under conditions of dense urban development, in this regard, methods for calculating bases and foundations are constantly improved using numerical non-linear methods. Today it is important to clarify the patterns and features of the three-dimensional interaction of strip foundations with the soil base in conditions of dense urban development with the use of various design soil models and comparison with field observations.

Assurance of reliability of building structures with minimum expenses of materials is determined to a greater extent by the degree of accuracy in the selection of the soil model, which most likely reflects the deformation properties of specific soil massif.

Corresponding author: natal03@mail.ru 
When calculating the deformations of foundations and comparing with the standard [1], the rigidity of the structure is usually not taken into account, in other words, non-uniformity of the foundation settlement is calculated without redistributing the loads between the foundations. In this regard, the choice of design soil models is one of the most important stages in the design. To solve these problems, a large number of software systems (SCAD Office, Lira, Robot Structural Analysis, Plaxis, Ansys, Abaqus, etc.) are currently used to implement more sophisticated calculation methods into the design practice, considering the stress-strain state of the bases foundations [2-9].

In these works, the iterative principles of accounting for the joint operation of the building and the foundation and ensuring the reliability and durability of buildings as elements of the "foundation-structure" system and features of design soil models and buildings models and methods for evaluating their stiffness properties [10, 11]. The article [12] provides recommendations on the choice of the design soil model for frame buildings on the raft foundation. In these papers various types of finite elements that simulate bases are proposed and examples of numerical base modeling by the finite element method are proposed and address the problem of choosing a soil model for making geotechnical calculations. [13-17].

\section{Purpose of study}

Comparison analysis of calculations of strip foundation settlement, taking into account the influence of adjoined building with different soil models. In the paper uses research method: descriptive, analysis, mathematical, methods for determining base deformations based on solutions of the theory of elasticity, methods for calculating structures on a deformable base.

\section{Main part}

The necessity to take into account the properties of soil foundations, which depend not only on the conditions of their natural occurrence, but also on the stress state, led researchers to create a large number of different soil models. In this article we will consider some of them: the Mohr-Coulomb model (perfect-plasticity) [13, 14, 18, 19], the Hardening-Soil model (isotropic hardening) [20-25], model of the Klepikov stiffness coefficient, whose parameters were determined taking into account the distribution capacity of the soil, as well as taking into account the elastic and plastic component of the settlement of the base.

Klepikov S.N. [26] proposed a model of variable stiffness coefficient, which is defined as the ratio of the average design pressure $\mathrm{P}(\mathrm{x})$ at the point $\mathrm{x}$ of the foundation to the foundation settlement $\mathrm{S}(\mathrm{x})$ at this point. The foundation settlement $\mathrm{S}(\mathrm{x})$ is determined by generally accepted methods (layer-by-layer summation method, linearly deformable layer method). The distribution of stresses in the soil mass in terms of plan and depth is taken according to the principle of superposition in accordance with the Boussinesq solution for an elastic half-space or the Flaman solution for plane deformation conditions. In its simplest form, the distribution of vertical stresses in depth at any point $\mathrm{x}$ located within the footing of the foundation, taking into account the influence of neighboring foundations or loaded areas, can be determined using the method of corner points. It is assumed that only elastic deformations of the soil have distribution properties, and plastic deformations do not have this property. In this regard, the total settlement $\mathrm{S}(\mathrm{x})$ is divided into elastic $\mathrm{Se}(\mathrm{x})$ and plastic $\mathrm{Sp}(\mathrm{x})$, determined by the method of layer-by-layer summation using respectively the residual (plastic) deformation modulus Epl and the elastic deformation modulus Eel. These modules are determined by the results of field tests of soils with dies or laboratory 
compression tests, taking into account the loading and unloading trajectories. Considering the above features, the stiffness coefficient is obtained by characterizing not only the physical properties of the soil, but also a variable that reflects the deformability of the bases only under a specific foundation or its section. With a modulus of total deformation equal to the modulus of elastic deformation, the model of variable stiffness coefficient has an overestimated distribution capacity of the soil, which is characteristic of an elastic halfspace. In the case when the ratio $E e l / E>6$, the distribution capacity of the soil is weak and can be neglected. In this regard, the ratio Eel/E has a significant impact on the results of calculations.

\subsection{Baseline data for calculations}

The existing building is a two-floor rectangular shape with symmetrically jutting out volumes in the plan. Overall dimensions in the extreme axes are $30.0 \times 17.0 \mathrm{~m}$. The structural design of the building is frameless. The main bearing structures are longitudinal and transverse walls. The spatial rigidity of the building in all directions is ensured by the joint work of the outer and partition walls of the building. The foundation is strip foundation of the foundation blocks with separate monolithic sections (Figure. 2). The building has a basement. The width of the foundation of outer walls is $700-1200 \mathrm{~mm}$., partition walls - 700-1100 mm. The foundation of the building has a complex pattern of application of vertical loads and their relatively low intensity. The magnitude of the regulatory loads on the strip foundation, depending on the axes, varies in the range from 55 $\mathrm{kN} / \mathrm{m}$ to $238 \mathrm{kN} / \mathrm{m}$. At present, a reinforced concrete 8 -floor frame building with dimensions in the plan of $\approx 30 \times 31.5 \mathrm{~m}$ has been attached to the wall along axis «1» in axes «A-K» (Figure. 2). The foundation of the new building is a monolithic slab $600 \mathrm{~mm}$ thickness. The marks of the base of the foundation of the existing and attached building are at the same elevation mark. Before the device of the excavation for the new building was dismantled the second floor of the existing two-story building. Foundations with a footing width of $700 \mathrm{~mm}$ along the axes $\langle\mathrm{B} »-\langle 2-8 »,\langle 3\rangle-\langle\mathrm{B}-\mathrm{C} »,\langle\langle 2\rangle-\langle\mathrm{B}-\mathrm{G}\rangle,\langle 3\rangle-\langle\mathrm{F}-\mathrm{G}\rangle$, $\langle\mathrm{F} »-\langle\langle 2-8\rangle$ were enhanced with a reinforced concrete cage up to the width of the footing of foundation $1 \mathrm{~m}$. The city of construction Minsk.

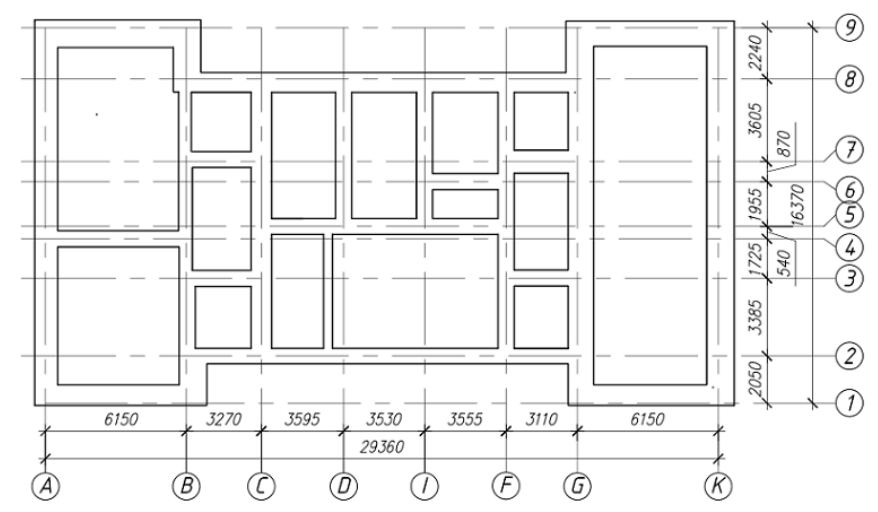

Fig. 1. Scheme of strip foundations of the existing building*.

* - axes are shown conditionally. 


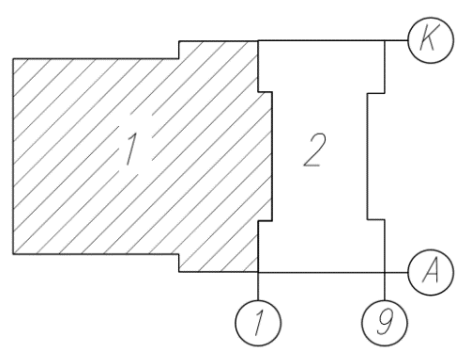

Fig. 2. Scheme of the existing and adjoined building*.

* - axes are shown conditionally.

1 - 8-storey building attached;

2 - 2 floor existing building.

According geological surveys, sands of medium strength and strong (layers-4,5,6,7,8,9) lie at the base of the foundations. Data on soils are presented in Table 1.

Table 1. Characteristic values of soils according to the results of Cone Penetration Test

\begin{tabular}{|c|c|c|}
\hline Layer & Soil & Cone resistance, qc, MPa \\
\hline 4 & medium sand, with medium strength & 5,1 \\
\hline 5 & medium sand, with medium strength & 10,7 \\
\hline 6 & medium sand, with medium strength & 21,9 \\
\hline 7 & coarse gravel sand, with medium strength & 4,9 \\
\hline 8 & coarse gravel sand, with medium strength & 10,6 \\
\hline 9 & coarse gravel strong sand & 26,9 \\
\hline
\end{tabular}

Under the part of the building in the axes $\langle\mathrm{G}-\mathrm{K} »-\langle\langle 9 »$ in the base of the foundations clayey sand with medium strength (Layer -3) occurs. The maximum thickness of this layer is $1.1 \mathrm{~m}$. The design value of ground coat specifications: $\mathrm{E}=8 \mathrm{MPa}, \gamma_{\mid I}=19,3 \mathrm{kN} / \mathrm{m}^{3}, \mathrm{c}_{1 \mid}=$ $23 \mathrm{MPa}, \varphi_{\| I}=23^{\circ}$. During the survey period, there was no groundwater in the wells and drilled holes.

\subsection{Calculation of settlement of strip foundations in applying the Mohr- Coulomb model (perfect-plasticity)}

The calculation was made in the program Plaxis 3D. Was created model a strip foundation with attached raft foundation of the new building, which is a real three-dimensional task (Figure. 3,4 ). The calculation stages displayed a true picture of the construction of a new building (dismantling of the floor of an existing building, excavation, etc.).

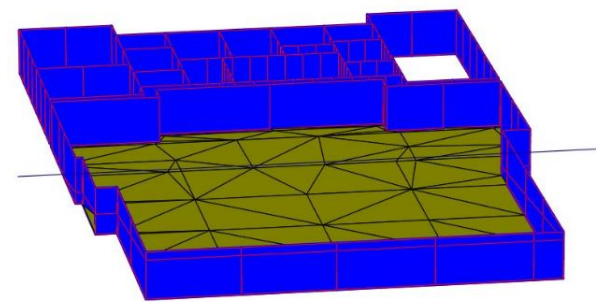

Fig. 3. Three-dimensional model of the strip foundation with the erected raft foundation.

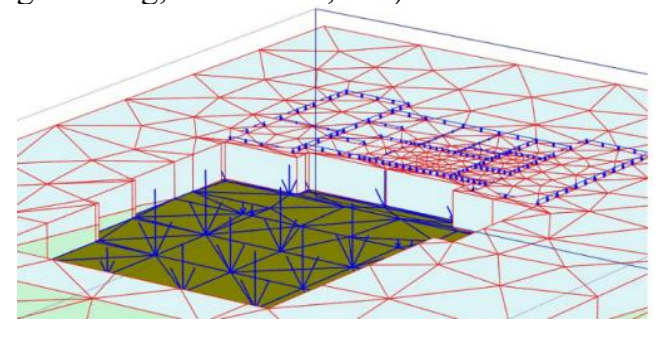

Fig. 4. Three-dimensional model with loads on the foundation. 
The characteristics of the soil layers 4-9 for the calculation were taken according to the results of Cone Penetration Test according to the recommendations [27-29].

Table 2. The results of calculations settlement of strip foundation in applying the Mohr-Coulomb model (perfect-plasticity).

\begin{tabular}{|c|c|c|}
\hline Foundations in the axes & Average settlement $S$, m & $\begin{array}{c}\text { Relative difference settlement } \\
\Delta \mathrm{S} / \mathrm{L}\end{array}$ \\
\hline «A-B» on axis «1» & $76,88^{*} * 10^{-3}$ & $0,33 * 10^{-3}$ \\
\hline$\langle\mathrm{B}-\mathrm{G} »$ on axis $\langle 2 »$ & $80,95 * 10^{-3}$ & $0,31 * 10^{-3}$ \\
\hline$\langle\mathrm{G}-\mathrm{K} »$ on axis $« 1 »$ & $84,77 * 10^{-3}$ & $0,314 * 10^{-3}$ \\
\hline$\langle\mathrm{A}-\mathrm{B} »$ on axis $\langle 4\rangle$ & $75,99 * 10^{-3}$ & $0,47 * 10^{-3}$ \\
\hline$\langle\mathrm{A}-\mathrm{B} »$ on axis $\langle 9 »$ & $73,76 * 10^{-3}$ & $0,189 * 10^{-3}$ \\
\hline$\langle\mathrm{B}-\mathrm{G} »$ on axis $\langle 88 »$ & $77,93 * 10^{-3}$ & $0,39 * 10^{-3}$ \\
\hline «G-K» on axis « $« » »$ & $83,98 * 10^{-3}$ & $0,82 * 10^{-3}$ \\
\hline on axis $\langle\mathrm{G} »$ & $82,89 * 10^{-3}$ & $0,137^{*} 10^{-3}$ \\
\hline on axis $« \mathrm{~K} »$ & $86,68 * 10^{-3}$ & $0,04 * 10^{-3}$ \\
\hline on axis $\langle\mathrm{F}\rangle$ & $81,64 * 10^{-3}$ & $0,314 * 10^{-3}$ \\
\hline on axis $« A »$ & $74,13 * 10^{-3}$ & $0,126^{*} 10^{-3}$ \\
\hline on axis $« B »$ & $76,03 * 10^{-3}$ & $0,26 * 10^{-3}$ \\
\hline on axis $« \mathrm{C} »$ & $77,72 * 10^{-3}$ & $0,328 * 10^{-3}$ \\
\hline
\end{tabular}

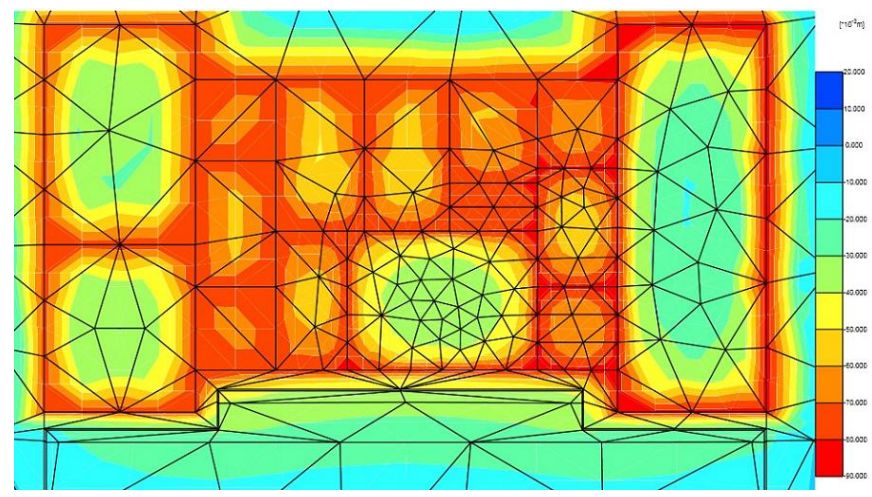

Fig. 5. Distribution of vertical deformations of the soil base in applying the Mohr-Coulomb model (perfect-plasticity).

\subsection{Calculation of settlement of strip foundations in applying the Hardening Soil model (isotropic hardening)}

In applying the Hardening Soil model, it becomes necessary to define additional soil parameters. However, these additional parameters are not included in the standard characteristics of soils and were not presented in the composition of the engineeringgeological report. Therefore, additional parameters of soils were defined according to recommendations [20-25]. 
Table 3. The results of calculations settlement of strip foundation in applying the Hardening Soil model (isotropic hardening).

\begin{tabular}{|c|c|c|}
\hline Foundations in the axes & Average settlement $\mathrm{S}, \mathrm{m}$ & $\begin{array}{c}\text { Relative difference settlement } \\
\Delta \mathrm{S} / \mathrm{L}\end{array}$ \\
\hline «A-B» on axis «1» & $84,04 * 10^{-3}$ & $0,17 * 10^{-3}$ \\
\hline «B-G» on axis «2» & $87,4 * 10^{-3}$ & $0,184 * 10^{-3}$ \\
\hline$\langle\mathrm{G}-\mathrm{K} »$ on axis $« 1 »$ & $89,36^{*} 10^{-3}$ & $0,83 * 10^{-3}$ \\
\hline «A-B» on axis $« 4 »$ & $97,64 * 10^{-3}$ & $0,384 * 10^{-3}$ \\
\hline$\langle\mathrm{A}-\mathrm{B} »$ on axis $\langle 9 »$ & $113,75^{*} 10^{-3}$ & $0,55^{*} 10^{-3}$ \\
\hline «B-G» on axis « $« 8 »$ & $108,18^{*} 10^{-3}$ & $0,223 * 10^{-3}$ \\
\hline$\langle\mathrm{G}-\mathrm{K} »$ on axis $\langle 99 »$ & $120,36 * 10^{-3}$ & $1,18^{*} 10^{-3}$ \\
\hline on axis $« \mathrm{G} »$ & $101,84 * 10^{-3}$ & $1,58 * 10^{-3}$ \\
\hline on axis $« \mathrm{~K} »$ & $108,22 * 10^{-3}$ & $1,91 * 10^{-3}$ \\
\hline on axis $« F »$ & $98,25 * 10^{-3}$ & $1,95 * 10^{-3}$ \\
\hline on axis $« A »$ & $98,51 * 10^{-3}$ & $1,72 * 10^{-3}$ \\
\hline on axis $« \mathrm{~B} »$ & $98,77^{*} 10^{-3}$ & $1,72 * 10^{-3}$ \\
\hline on axis $« \mathrm{C} »$ & $96,53 * 10^{-3}$ & $1,69 * 10^{-3}$ \\
\hline
\end{tabular}

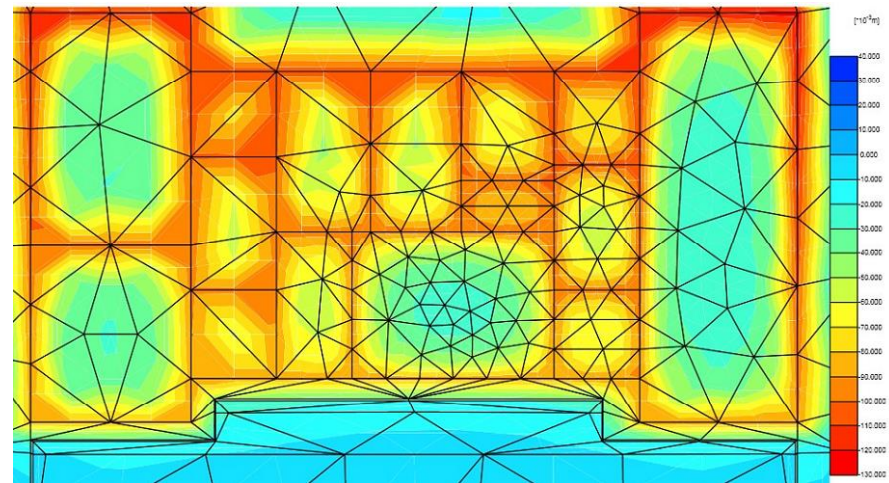

Fig. 6. Distribution of vertical deformations of the Hardening Soil model (isotropic hardening).

\subsection{Calculation of settlement of strip foundations in applying the model of the Klepikov stiffness coefficient with the ratio $E e l / E=3$ and $E e l / E=5$}

The indicated ratios of the moduli of elastic and total deformation are taken as the boundaries of the range of recommended values in the reference tables for the indicated soils, as there are no results of the modulus of elastic deformations to define.

Table 4. The results of calculations settlement of strip foundation in applying the Model of the Klepikov stiffness coefficient with the ratio $\mathrm{Eel} / \mathrm{E}=3$ and $\mathrm{Eel} / \mathrm{E}=5$.

\begin{tabular}{|c|c|c|c|c|}
\hline \multirow[b]{2}{*}{$\begin{array}{c}\text { Foundations in the } \\
\text { axes }\end{array}$} & \multicolumn{2}{|c|}{$\mathrm{Eel} / \mathbf{E}=\mathbf{3}$} & \multicolumn{2}{|c|}{$\mathrm{Eel} / \mathbf{E}=\mathbf{5}$} \\
\hline & $\begin{array}{c}\text { Average } \\
\text { settlement } S, \\
\mathbf{m}\end{array}$ & $\begin{array}{c}\text { Relative } \\
\text { difference } \\
\text { settlement } \Delta S / L\end{array}$ & $\begin{array}{c}\text { Average } \\
\text { settlement } S, \\
\mathbf{m}\end{array}$ & $\begin{array}{c}\text { Relative } \\
\text { difference } \\
\text { settlement } \Delta S / L\end{array}$ \\
\hline$\langle\mathrm{A}-\mathrm{B} »$ on axis $« 1 »$ & $85,14 * 10^{-3}$ & $3,82 * 10^{-3}$ & $73,88^{*} 10^{-3}$ & $1,54 * 10^{-3}$ \\
\hline$\langle\mathrm{B}-\mathrm{G} »$ on axis $« 2 »$ & $86,17 * 10^{-3}$ & $0,14 * 10^{-3}$ & $75,6^{*} * 10^{-3}$ & $0,42 * 10^{-3}$ \\
\hline$\langle\mathrm{G}-\mathrm{K} »$ on axis $\langle 1 »$ & $79,2 * 10^{-3}$ & $1,52 * 10^{-3}$ & $70,22 * 10^{-3}$ & $0,2 * 10^{-3}$ \\
\hline$\langle\mathrm{A}-\mathrm{B} »$ on axis $\langle 4\rangle$ & $42,75^{*} 10^{-3}$ & $0,96 * 10^{-3}$ & $45,42 * 10^{-3}$ & $1,92 * 10^{-3}$ \\
\hline$\langle\mathrm{A}-\mathrm{B} »$ on axis $\langle 9\rangle$ & $56,62 * 10^{-3}$ & $0,1 * 10^{-3}$ & $73,76^{*} 10^{-3}$ & $0,189 * 10^{-3}$ \\
\hline$\langle\mathrm{B}-\mathrm{G} »$ on axis $\langle 8 »$ & $68,33 * 10^{-3}$ & $0,11 * 10^{-3}$ & $65,95^{*} 10^{-3}$ & $0,76^{*} * 10^{-3}$ \\
\hline
\end{tabular}




\begin{tabular}{|c|c|c|c|c|}
\hline$\langle\mathrm{G}-\mathrm{K} »$ on axis $\langle(9 »\rangle$ & $55,21 * 10^{-3}$ & $1,01 * 10^{-3}$ & $54,84 * 10^{-3}$ & $1,16^{*} 10^{-3}$ \\
\hline on axis «G»» & $76,78 * 10^{-3}$ & $1,73 * 10^{-3}$ & $70,2 * 10^{-3}$ & $0,43 * 10^{-3}$ \\
\hline on axis $\langle K K »$ & $71,22 * 10^{-3}$ & $1,04 * 10^{-3}$ & $70,14 * 10^{-3}$ & $0,86^{*} 10^{-3}$ \\
\hline on axis $\langle\mathrm{F} »$ & $75,33 * 10^{-3}$ & $1,04 * 10^{-3}$ & $68,77^{*} 10^{-3}$ & $0,59 * 10^{-3}$ \\
\hline on axis «A» & $74,56 * 10^{-3}$ & $1,01 * 10^{-3}$ & $72,02 * 10^{-3}$ & $0,69^{*} 10^{-3}$ \\
\hline on axis $« B »$ & $76,81 * 10^{-3}$ & $2,53 * 10^{-3}$ & $70,47 * 10^{-3}$ & $1,96 * 10^{-3}$ \\
\hline on axis $« \mathrm{C} »$ & $67,92 * 10^{-3}$ & $1,27 * 10^{-3}$ & $69,11 * 10^{-3}$ & $1,17 * 10^{-3}$ \\
\hline
\end{tabular}

\section{The results of the executed researches}

Table 5. The results of calculations of the average settlement the strip foundation for various desing soil models relative to the average settlement of the strip foundation when calculated by the MohrCoulomb model.

\begin{tabular}{|c|c|c|c|}
\hline $\begin{array}{c}\text { Foundations in the } \\
\text { axes }\end{array}$ & $\begin{array}{c}\text { Hardening Soil } \\
\text { Model }\end{array}$ & $\begin{array}{c}\text { Model of the Klepikov } \\
\text { stiffness coefficient } \\
\text { Eel/E=3 }\end{array}$ & $\begin{array}{c}\text { Model of the Klepikov } \\
\text { stiffness coefficient } \\
\text { Eel/E }=5\end{array}$ \\
\hline «A-B» on axis «1» & $8.52 \%$ & $9.70 \%$ & $-4.06 \%$ \\
\hline$\langle\mathrm{B}-\mathrm{G}\rangle$ on axis $\langle 2\rangle$ & $7.38 \%$ & $6.06 \%$ & $-7.08 \%$ \\
\hline «G-K» on axis «1» & $5.14 \%$ & $-7.03 \%$ & $-20.72 \%$ \\
\hline «A-B» on axis «4»» & $22.17 \%$ & $-67.31 \%$ & $-77.75 \%$ \\
\hline$\langle\mathrm{A}-\mathrm{B} »$ on axis $\langle 9\rangle$ & $35.16 \%$ & $-30.27 \%$ & $0.00 \%$ \\
\hline «B-G» on axis « $\langle 8 »$ & $27.96 \%$ & $-14.05 \%$ & $-18.17 \%$ \\
\hline$\langle\mathrm{G}-\mathrm{K} »$ on axis $\langle 9 » »$ & $30.23 \%$ & $-52.11 \%$ & $-53.14 \%$ \\
\hline on axis $\langle\mathrm{G} »$ & $18.61 \%$ & $-7.96 \%$ & $-18.08 \%$ \\
\hline on axis «K» & $19.90 \%$ & $-21.71 \%$ & $-23.58 \%$ \\
\hline on axis $\langle\mathrm{F}\rangle$ & $16.91 \%$ & $-8.38 \%$ & $-18.71 \%$ \\
\hline on axis «A» & $24.75 \%$ & $0.58 \%$ & $-2.93 \%$ \\
\hline on axis «B» & $23.02 \%$ & $1.02 \%$ & $-7.89 \%$ \\
\hline on axis $« \mathrm{C} »$ & $19.49 \%$ & $-14.43 \%$ & $-12.46 \%$ \\
\hline
\end{tabular}

Table 6. The results of calculations of the relative difference settlement the strip foundation for various desing soil models relative to the average settlement of the strip foundation when calculated by the Mohr-Coulomb model.

\begin{tabular}{|c|c|c|c|}
\hline Foundations in the axes & $\begin{array}{c}\text { Hardening Soil } \\
\text { Model }\end{array}$ & $\begin{array}{c}\text { Model of the } \\
\text { Klepikov stiffness } \\
\text { coefficient } \text { Eel/ } \mathbf{E}=\mathbf{3}\end{array}$ & $\begin{array}{c}\text { Model of the Klepikov } \\
\text { stiffness coefficient } \\
\text { Eel } / \mathbf{E}=\mathbf{5}\end{array}$ \\
\hline$\langle\mathrm{A}-\mathrm{B} »$ on axis $« 1 »$ & $-94.12 \%$ & $85.60 \%$ & $64.29 \%$ \\
\hline$\langle\mathrm{B}-\mathrm{G} »$ on axis $« 2 »$ & $-68.48 \%$ & $-121.43 \%$ & $26.19 \%$ \\
\hline «G-K» on axis «1» & $62.17 \%$ & $79.34 \%$ & $-57.00 \%$ \\
\hline «A-B» on axis $« 4 »$ & $-22.40 \%$ & $51.04 \%$ & $75.52 \%$ \\
\hline$\langle\mathrm{A}-\mathrm{B} »$ on axis $\langle 9 »$ & $65.64 \%$ & $-89.00 \%$ & $0.00 \%$ \\
\hline$\langle\mathrm{B}-\mathrm{G} »$ on axis $« 8 »$ & $-74.89 \%$ & $48.68 \%$ & $-254.55 \%$ \\
\hline «G-K» on axis « $\langle 9 »$ & $30.51 \%$ & $18.81 \%$ & $29.31 \%$ \\
\hline on axis $« \mathrm{G} »$ & $91.33 \%$ & $92.08 \%$ & $68.14 \%$ \\
\hline on axis «K» & $97.91 \%$ & $96.15 \%$ & $95.35 \%$ \\
\hline on axis $\langle\mathrm{F}\rangle$ & $83.90 \%$ & $69.81 \%$ & $46.78 \%$ \\
\hline on axis «A» & $92.67 \%$ & $87.52 \%$ & $81.74 \%$ \\
\hline on axis $\langle\mathrm{B} »$ & $84.88 \%$ & $89.72 \%$ & $86.73 \%$ \\
\hline on axis $« \mathrm{C} »$ & $80.59 \%$ & $74.17 \%$ & $71.97 \%$ \\
\hline
\end{tabular}




\section{Comparison with the results of field observations}

Geodesic monitoring of the deformations of the 2-floor building was carried out from the moment of pouring the first floor slab to the pouring of the eighth floor slab of the building. Deformations for the study period amounted to no more than $5 \mathrm{~mm}$, without taking into account the error of the measuring instruments.

Table 7. The results of calculations the settlement strip foundation when compared with field observations.

\begin{tabular}{|l|c|c|}
\hline \multicolumn{1}{|c|}{ The design soil model } & Settlement, $\mathbf{~ m}$ & $\begin{array}{c}\text { Deviation from field } \\
\text { observations, } \%\end{array}$ \\
\hline the Mohr-Coulomb model (perfect-plasticity) & $5,82 * 10^{-3}$ & 14,1 \\
\hline the Hardening-Soil model (isotropic hardening) & $16,11^{*} 10^{-3}$ & 68,96 \\
\hline $\begin{array}{l}\text { model of the Klepikov stiffness coefficient with the } \\
\text { ratio Eel/E=3 }\end{array}$ & $20^{*} 10^{-3}$ & 75 \\
\hline $\begin{array}{l}\text { model of the Klepikov stiffness coefficient } \\
\text { Eel/E=5 }\end{array}$ & $12,4^{*} 10^{-3}$ & 59,68 \\
\hline
\end{tabular}

\section{Conclusions}

1. The analysis performed showed that the Hardening-Soil model (isotropic hardening) in this case exaggerates the distribution properties of the soil, but refines the behavior of the real soil (Figure 6). In this case, an overestimation of the results could be due to the fact that the missing data for the calculation were taken according to recommendations, and not according to laboratory test data.

2. The Mohr-Coulomb model (perfect-plasticity) takes into account the basic properties of the soil (for example, elastic behavior under low loads). In this case, since relatively small loads were applied to the strip foundation, the deformations of the strip foundation were small (Table 3), therefore the Mohr-Coulomb model most correctly reflects the behavior of the soil bases. Also, the correctness of the applicability of this model can be compared with field observations of the vertical deformations (Table 7).

3. In this work, when applying the model of the base in the form of a variable Klepikov stiffness coefficient, the ratio of the elastic deformation modulus to the total deformation modulus equal to 3 and 5 was considered. With these ratios, significant deviations from the results of field observations were obtained. An increase in the ratio of the elastic deformation modulus to the total deformation modulus total deformation would allow one to obtain results closer to field observations, however, with the ratio Eel/E $>6$, it is allowed to neglect the distribution capacity of the soil, which is obvious and fair for this design situation.

4. It should be noted that the choice of soil model depends on many factors, for example, soil conditions, loading conditions, etc. Therefore, the choice of the most adequate soil model must be selected particularly for each design case.

\section{References}

1. Standard TKP 45-5.01-67-2007 (02250) Slab foundations. Rules of designing. Minsk (2008)

2. L. A. Igosheva, V. I. Kleveko, Transport. Transportnye sooruzheniya. Ehkologiya, 3 pp.74-86 (2014)

3. S. V. Kaloshina, A. B. Ponomarev, Vestnik Volgogradskogo gosudarstvennogo arkhitekturno-stroitel'nogo universiteta. Seriya: Stroitel'stvo i arkhitektura, 17 pp.24-28 (2010) 
4. A. N. Bogomolov, A. N. Ushakov, Osnovaniya Fundamenty Mekhanika Gruntov, 6 pp.24-28 (2011)

5. L. A. Strokova, Vestnik Tomskogo gosudarstvennogo universiteta, 367 pp.190-194 (2013)

6. E. S. Egorova, A. V. Ioskevich, V. V. Ioskevich, K. N. Agishev, V. YU. Kozhevnikov, Stroitel'stvo unikal'nykh zdanij i sooruzhenij, 3 pp.31-60 (2016)

7. Mohanned Q. Waheed, Noor M. Asmael, International Journal of Civil Engineering and Technology, 9-10 pp.1223-1230 (2018)

8. G. Abate, C. Caruso, M. R. Massimino, M. Maugeri, International Journal Geomechanics and Geoengineering, 3-1 pp.27-40 (2008)

9. E. S. Utenov, A. T. Mukhamedzhanova, A. Z. Zhusupbekov, B. O. Kaldanova, S. N. Sotnikov, Osnovaniya Fundamenty Mekhanika Gruntov, 1 pp.9-15 (2017)

10. B. A. Garagash, Nadezhnost' prostranstvennykh reguliruemykh sistem «osnovaniesooruzhenie» pri neravnomernykh deformatsiyakh osnovaniya (Moscow: ASV, 2012)

11. V. A. Il'ichev, R. A. Mangushev, Spravochnik geotekhnika. Osnovaniya, fundamenty $i$ podzemnye sooruzheniya (Moscow: ASV, 2014)

12. O. Petrakov, V. Yarkin, K. Bryzhata, Modern industrial and civil construction, 10-4 pp.237-243 (2014)

13. L. A. Strokova, Izvestiya Tomskogo politekhnicheskogo universiteta, 313-1 pp.69-74 (2008)

14. V. I. Matselya, I. N. Seelev, A. V. Lekontsev, R. R. Khafizov, N. N. Panasenko, A. V. Sinelshchikov, P. V. Yakovlev, Vestnik Astrakhanskogo gosudarstvennogo tekhnicheskogo universiteta, 1(63) pp.23-31 (2017)

15. V. A. Barvashov, Osnovaniya Fundamenty Mekhanika Gruntov, 4 pp.25-27 (1979)

16. V. V. Orekhov, Osnovaniya Fundamenty Mekhanika Gruntov, 1 pp.2-4 (2016)

17. S. V. Kaloshina, E. A. SHalamova, M. A. Bezgodov, Akademicheskij vestnik UralNIIproekt RAASN, 3 pp.72-78 (2016)

18. R. B. J. Brinkgreve, W. M. Swolfs, E. Engine, Plaxis users manual (Rotterdam: Balkema, 2002)

19. O. V. Sokolova, Inzhenerno-stroitel'nyj zhurnal, 4 pp.10-16 (2014)

20. A. B. Fadeev, CHislennye metody raschetov v prakticheskoj geotekhnike: sb. statej nauchn.-tekhn. konf. SPbGASU pp.13-20 (2012)

21. T. Schanz, P. A. Vermeer, P. G. Bonnier, Beyond 2000 in computational geotechnics pp.281-296 (1999)

22. P. A. Vermeer, Geotechnique, 28-4 pp.413-433 (1978)

23. M. I. Kudasheva, S. V. Kaloshina, KHimiya. EHkologiya. Urbanistika, 1 pp.261-265 (2017)

24. R. V. Mel'nikov, R. KH. Sagitova, Akademicheskij vestnik UralNIIproekt RAASN, 3 pp.79-86 (2016)

25. A. Z. Ter-Martirsjan, A. Ju. Mirnyj, E. S. Sobolev, Geotechnics J., 1 66-2 (2016)

26. S. N. Klepikov, Raschet sooruzhenij na deformiruemom osnovanii (Kiev: NIISK, 1996)

27. G. G. Boldyrev, A. V. Mel'nikov, E. V. Merkul'ev, G. A. Novichkov, Inzhenernye izyskaniya, 14 pp.28-46 (2013)

28. P. K. Robertson, K. L. Cabal, Cone Penetration Testing for Geotechnical Engineering 6th Edition (California: Gregg Drilling \& Testing, Inc, 2015)

29. A. EH. Kurilovich, Vestnik Voronezhskogo gosudarstvennogo universiteta. Seriya: Geologiya, 2 pp.184-187 (2013) 